\title{
Comparatist Postcolonial Studies: A Review Article of Books by Coundouriotis, Matthews Green, Yeager, and Gould, Vautier, and Canadian Literature
}

\author{
Angeline O’Neill \\ University of Notre Dame, Australia
}

Follow this and additional works at: https://docs.lib.purdue.edu/clcweb

C.

Part of the Comparative Literature Commons, and the Critical and Cultural Studies Commons

Dedicated to the dissemination of scholarly and professional information, Purdue University Press selects, develops, and distributes quality resources in several key subject areas for which its parent university is famous, including business, technology, health, veterinary medicine, and other selected disciplines in the humanities and sciences.

CLCWeb: Comparative Literature and Culture, the peer-reviewed, full-text, and open-access learned journal in the humanities and social sciences, publishes new scholarship following tenets of the discipline of comparative literature and the field of cultural studies designated as "comparative cultural studies." Publications in the journal are indexed in the Annual Bibliography of English Language and Literature (Chadwyck-Healey), the Arts and Humanities Citation Index (Thomson Reuters ISI), the Humanities Index (Wilson), Humanities International Complete (EBSCO), the International Bibliography of the Modern Language Association of America, and Scopus (Elsevier). The journal is affiliated with the Purdue University Press monograph series of Books in Comparative Cultural Studies. Contact: <clcweb@purdue.edu>

\section{Recommended Citation}

O’Neill, Angeline. "Comparatist Postcolonial Studies: A Review Article of Books by Coundouriotis, Matthews Green, Yeager, and Gould, Vautier, and Canadian Literature." CLCWeb: Comparative Literature and Culture 3.4 (2001): <https://doi.org/10.7771/1481-4374.1138>

This text has been double-blind peer reviewed by $2+1$ experts in the field.

The above text, published by Purdue University Press (CPurdue University, has been downloaded 1180 times as of 11/ 07/19. Note: the download counts of the journal's material are since Issue 9.1 (March 2007), since the journal's format in pdf (instead of in html 1999-2007).

This document has been made available through Purdue e-Pubs, a service of the Purdue University Libraries. Please contact epubs@purdue.edu for additional information.

This is an Open Access journal. This means that it uses a funding model that does not charge readers or their institutions for access. Readers may freely read, download, copy, distribute, print, search, or link to the full texts of articles. This journal is covered under the CC BY-NC-ND license. 


\section{PURDUE}

UNIVERSITY PRESS <http://www.thepress. purdue.edu>

\section{CLCWeb: Comparative Literature and Culture}

ISSN 1481-4374 <http://docs.lib.purdue.edu/clcweb> Purdue University Press @Purdue University

CLCWeb: Comparative Literature and Culture, the peer-reviewed, full-text, and open-access learned journal in the humanities and social sciences, publishes new scholarship following tenets of the discipline of comparative literature and the field of cultural studies designated as "comparative cultural studies." In addition to the publication of articles, the journal publishes review articles of scholarly books and publishes research material in its Library Series. Publications in the journal are indexed in the Annual Bibliography of English Language and Literature (Chadwyck-Healey), the Arts and Humanities Citation Index (Thomson Reuters ISI), the Humanities Index (Wilson), Humanities International Complete (EBSCO), the International Bibliography of the Modern Langua-ge Association of America, and Scopus (Elsevier). The journal is affiliated with the Purdue University Press monog-raph series of Books in Comparative Cultural Studies. Contact: <clcweb@purdue.edu>

Volume 3 Issue 4 (December 2001) Book Review Article Angeline O'Neill,

"Comparatist Postcolonial Studies: A Review Article of Books by Coundouriotis, Matthews Green, Yeager, and Gould, Vautier, and Canadian Literature" <http://docs.lib.purdue.edu/clcweb/vol3/iss4/7>

Contents of CLCWeb: Comparative Literature and Culture 3.4 (2001)

<http://docs.lib.purdue.edu/clcweb/vol3/iss4/> 


\section{Angeline O'NEILL}

\section{Comparatist Postcolonial Studies: A Review Article of Books by Coundouriotis, Matthews Green, Yeager, and Gould, Vautier, and Canadian Literature}

In this review article, I discuss Eleni Coundouriotis's Claiming History: Colonialism, Ethnography and the Novel (New York: Columbia UP, 1999), Marie Vautier's New World Myth: Postmodernism and Postcolonialism in Canadian Fiction (Montréal: McGill-Queen's UP, 1998), Mary Jean Matthews Green, Jack A. Yeager, and Karen Gould, eds., Postcolonial Subjects: Francophone Women Writers (Minneapolis: U of Minnesota P, 1996), and Postcolonial Identities, a thematic issue of the journal Canadian Literature (1996, Issue Number 146).

With increasing awareness of the value of a comparative approach to literature and culture, texts such as Marie Vautier's New World Myth: Postmodernism and Postcolonialism in Canadian Fiction, Eleni Coundouriotis's Claiming History: Colonialism, Ethnography, and the Novel, and the collection of essays in Postcolonial Subjects and Postcolonial Identities demand a readership for a better understanding of ourselves, each other, the world we live in, and the way we represent each of these. Together, such texts wrestle with some of the most stimulating issues and difficult problems facing all interested and working in the humanities today. Foremost among these are issues of national, cultural, and individual identity viewed in the context of cross-cultural interactions -- from Vautier's concern with the interaction between Quebec and English-speaking Canada to the focus on a cultural and linguistic métissage borne of the position of Francophone women writers writing from "beyond the hexagon" in Postcolonial Subjects. Coundouriotis addresses what she describes as "an urgent need to theorize a practice of history within postcolonial studies" (19), suggesting a paradigm of dissidence rather than resistance. In so doing, she focuses on both literary history and history in literature. Interdisciplinarity features in each of the texts, as language and identity engage issues of gender, race, ethnicity, culture, and nation. Relations between literature, language, anthropology, and history are foregrounded alongside what can be described as cross-cultural borrowing and a new theory of comparative poetics. In this way, some of the major problems facing comparatists come to light and are dealt with in a thought-provoking manner. Readers are invited to consider the diversity of topics, authors, disciplines, and intellectual traditions crucial to comparative studies and its manifestation in the tensions between such as the individual and the collective, autobiography and history, and writing and orality.

Comparatist Jola Skulj writes that "comparatively speaking, the creativity of individual cultures exists through permanent re-interpretations of their own image of identity" (see Jola Skulj, "Comparative Literature and Cultural Identity," CLCWeb: Comparative Literature and Culture: $A$ WWWeb Journal 2.4 [2000]: <http://docs.lib.purdue.edu/clcweb/vol2/iss4/5/>) and this is indeed so in each of the texts under consideration here. Before examining them and their respective methodological approaches in detail, however, I refer to the discipline of comparative literature and those issues central to comparative studies many of which concern the authors and editors whose texts are reviewed here. In particular, their various approaches to the Self-Other paradigm and the implications of this for notions of race and nation are of importance. To start with, if we agree with the proposition that "Comparative Literature means the knowledge of more than one national language and literature, and/or it means the knowledge and application of other disciplines in and for the study of literature ... Comparative Literature has an ideology of inclusion of the Other, be that a marginal literature in its several meanings of marginality, a genre, various text types, etc." (see Steven Tötösy de Zepetnek, Comparative Literature: Theory, Method, Application. Amsterdam-Atlanta, GA: Rodopi, 1998. 13), the editors of and contributors to Postcolonial Subjects explore their fields of study precisely in this context. The papers demonstrate the use and impact of the knowledges proposed in comparative literature competently. With focus on the SelfOther problem, the authors of the papers discuss diverse notions of "border crossings" -- whether physical or resulting from a diversity of languages, ethnicities, and races co-existing in a single national territory. In particular, the female body is seen as "a space of cultural exchange [...] a site of literal métissage for the blending of race" (xix). The areas of study are with focus on contemporary women writing in French from as far afield as Africa and the Indian Ocean, the Middle East, 
the Caribbean, Southeast Asia, Quebec, and other French-speaking regions of Canada, for all of whom the French language is a site of struggle against both colonization and "the more subtle imperialistic forces at work in postcolonial situations" (xi). The editors are quick to point out, however, that the collection is neither an attempt to define francophonie nor to create an alternative canon but rather to provide a forum for the wealth of work by Francophone women from various regions and cultures. So too, they are sensitive to the temptation to promote "a reductionist, composite, female francophone 'Other' that would deny distinctions among these writers" (xv). The approach is cross-cultural and transcultural and a multiplicity of positions and modes of critical analysis are evident. Accordingly, the collection is organized into three sections: "Situating the Self: History, Rememory, Story," "Border Crossings," and "Engendering the Postcolonial Subject." The fact that the editors themselves as well as the contributors include both women and men, and that the analyses range from specifically historical contextualisation to contemporary feminist theory, further strengthens the collection.

Marie Vautier's New World Myth challenges the simplistic and politically correct approach to the Self-Other paradigm, arguing that in fact such an approach hinders attempts by some mainstream writers "to open up textual space in which to explore various manifestations of differing cultural representations" (xvii). In particular, Vautier focuses on non-Aboriginal representations of Amerindians, developing her thesis simultaneously that we must be aware of "the limitations of the self/other argument in critical appraisals of the multitiered postcolonial situations in Englishspeaking Canada and Quebec" (xx). By carefully examining in the light of theories of postcolonialism and postmodernism the reworkings of some historical, literary, and religious myths and political ideologies in six historiographic novels from Quebec and English-speaking Canada (published between 1975 and 1985), Vautier explains what she terms "New World Myth," a notion that "works against traditional assumptions about the universality and transhistoricity of myth" (ix). New World Myth reclaims the past, characterised by "postmodern indeterminacy, complex postcolonial attitudes, a questioning of history, and a developing self-consciousness that creates provisional and relative identities" (xi). In so doing, the concept advocates the existence of many postcolonialisms and challenges the assumption that all postcolonial texts are writing back to a single center.

Similarly, Eleni Coundouriotis is interested in extending understandings of colonialism and postcolonialism in her study of several African novels written in French and English. In Claiming History Coundouriotis focuses on the relationship between history and literature. As Coundouriotis acknowledges, the text could be described as literary history but it also examines history in literature and the processes by which her chosen authors reclaim it: the processes of reclamation, resistance, dissidence, and transgression are crucial. Interestingly, in Claiming History dissidence is a more immediately useful notion than resistance. It proclaims difference from within and, like Vautier's concern with "multitiered postcolonial situations," directs our attention towards the internal dynamics of a community (20). By "transgression" Coundouriotis "a deliberate crossing of the limits of representation to invent new terms beyond the Manichean opposition of colonial and anticolonial" (165) which, she argues, inevitably followed a period of "oppressive nationalisms" that in turn had followed colonialism. With a series of well-chosen examples from the novels of René Maran, Paul Hazoumé, Chinua Achebe, Yambo Ouologuem, and Ben Okri, Coundouriotis examines the difficulties encountered by Africans writing historical novels in the face of previous acts of narrative oppression whose historicism as subjects of history has always been to some degree prefigured by the historiographical enterprises of the European colonizers. In discussing the relationship between history and fiction, Coundouriotis traces the development of a hybrid discourse wherein new authorial positions are established through narratives which challenge established perspectives.

Recognition of the dynamism of literature and language is integral to our understanding of history and our place in it, whether in an oral or written tradition. As Bakhtin writes in "Discourse in the Novel," "stratification and heteroglossia widen and deepen as long as language is alive and developing. Alongside the centripetal forces, the centrifugal forces of language carry on their uninterrupted work; alongside verbal-ideological centralization and unification, the uninter- 
rupted processes of decentralisation and disunification go forward" (Mikhail Bakhtin, "Discourse in the Novel." Trans. Caryl Emerson and Michael Holquist. Critical Theory since Plato. Ed. Hazard Adams. New York: Harcourt Brace, 1971. 665-78. 668). The implications of this view for a sense of identity are significant. In the 146th issue of Canadian Literature, devoted to Postcolonial Identities, Neil ten Kortenaar explores this question in his paper "The Trick of Divining a Postcolonial Identity: Margaret Laurence Between Race and Nation." According to Kortenaar, Laurence's novel celebrates future creolization resulting from a challenge to the colonial status quo in the form of a union between the settlers and indigenes in Canada: "a union not a dilution" (21). The novel sets out to replace race by nation, maintaining that identities are human constructs. Yet Kortenaar asks: "Why should the national identity be more valid than class, regional or racial identity? Why should the national narrative be accepted as the truest one?" (30) and he proceeds to argue that the field for a comparative study of identities "must belong to different orders: nations and empires; nationalisms and sexualities; genders and classes" (30). As we know, each of these orders is, to a certain extent, possessed by its own language, literature, and interpretation of history -centrifugal forces working against while at the same time, Bakhtin would argue, ultimately contributing to the "unity of the reigning conversational and literary language" (669).

Issues of race, nation, and nationalism and their implications for the Self-Other paradigm interest all authors in the texts under discussion here. In a chapter devoted to "Temporality and the Geographies of the Nation" and taking Okri's The Famished Road as a test-case, Coundouriotis explores Nigerian novels that dissent from official narratives of nationalism while yet "recommitting to the nation, a nation reshaping in postindependence" (142). In a fascinating discussion of the relationship between geography and historiography, she asks where history fits between geography and state politics and whether, as Neil ten Kortenaar asks in his paper, history must be "invented anew to make sense of geographical boundaries and forge a nation? Or must be accountable for the incoherences of real circumstances?" (144). Should history expose myth? If so, Coundouriotis suggests, geography becomes a storytelling paradigm, a way of divining meaning from the points of contact of a variety of places. She proceeds to explore several theories of nationalism -- specifically those of Benedict Anderson, Homi Bhabha, and Mikhail Bakhtin -- and decides that the Western world's paradigms of historicity have been "used up," resulting in a "constant presentness" requiring the invention of a new historical paradigm (156). Okri, she contends, exemplifies this process.

So too, in Postcolonial Subjects, the editors and the contributors to the volume focus on history and nationalism. In her interesting essay "The Past Our Mother: Marie-Claire Blais and the Question of Women in the Quebec Canon," Matthews Green examines the important role women writers have played in Quebec in recent years; a role apparently made all the more problematic considering the centrality of the patriarch -- whether father, the pope, or a (male) god -- in traditional Quebec society. Blais is given as an example of a woman whose work has "give[n] form to a reality that is recognised by [her] readers not as exclusively feminine but rather, as essentially Québécois" (76). In a thesis that is complemented by the final essay in this collection, Françoise Lionnet's "Logique métisses," Matthews Green argues convincingly that, at a time when women writers are increasingly important cultural voices, their representation of the mother-daughter relationship "enacts issues at stake in evolving concepts of Quebec identity" (62). While exploring the same broad issue of Francophone women writers taking possession of the language of Racine, Voltaire, and Proust and using it to communicate their own experiences, C. Makward discusses in her paper "Cherchez la Franco-femme" Francophone women writers from the Caribbean, Frenchspeaking Switzerland, and Algeria who initially appear to have little in common, other than the fact that -- metaphorically and/or physically -- they have been "driven into exile, to preserve their freedom of thought, lifestyle and writing" (118). Initially, they seem to lack a common feminist ideology. Makward proceeds, however, to uncover a shared "gynocentric and constructive vision, a positive feminine identification that short-circuits maternity (not in the lives of the writers but in their fiction)" (120). In this way, both Matthews Green and Makward explore the vanquishment of archetypes of femininity and the corresponding emergence of postcolonial identity. 
In considering the role of the Other in defining the Self, in Postcolonial Identities Neil ten Kortenaar argues that the issue of cultural identity moves far beyond one's own national borders and that, in fact, national cultures assume their form on the borders of other influential cultures -a point with which both Matthews Green and Makward would agree. Vautier considers this at a more individual level when she expresses her concern that "in politically correct academic circles [the Self-Other paradigm] appears to be working against the postcolonial practices" in some mainstream texts (xvii). So too, it is central to Coundouriotis's discussion of the (re)claiming of history by African writers. This brings us to the question of cross-genre and cross-disciplinary writing: in particular to the realm of anthropological and ethnographic works as literature, an important area in the work of comparatists in general. If we agree with Foucault that new narratives arise out of the silences of the previous episteme, then what we find in this body of literature is a snapshot of the anthropologists and ethnographers themselves, which now offers others in their profession, as well as artists, scientists and critics, an opportunity to contribute to the body of knowledge borne of the interpenetration of disciplines. As Frantz Fanon is quoted as saying by the editors in Postcolonial Subjects, "to speak means to be in a position to use a certain syntax, to grasp the morphology of this or that language, but it means above all to assume a culture, to support the weight of a civilization" (xi). In the introduction to her Claiming History, Coundouriotis gives an example of this when she describes the way that, "cast as travelogue, the ethnographic monograph diminishes the distance between self and other by the observer's travel to the space occupied by the observed" (12). However, she continues, "in the written account, the distance travelled is metaphorically converted into temporal distance" (13). In this way, ethnography may be seen as an attitude which establishes narrative authority and privilege, an attitude called into question by practitioners of comparative studies. And this link between history, ethnography, and literature underlies Vautier's discussion of métissage in the works of Jovette Marchessault, Rudy Wiebe, and Joy Kogawa, among others. In dealing with the construction of identity, however, Vautier mentions "the practice of métissage in historical French Canadian/Amerindian relations" (107), by which she means a movement between groups resulting in "a constantly shifting, blurring, blending, conflation and reconfiguration" of them (216). She calls into question the view of language as a barrier, a sign of absolute Otherness. In fact, she maintains, the practice of métissage ultimately leads to a less confrontational notion of difference and multiplicity. I would add that the cross-disciplinary reading of anthropological and ethnographic works as literature in recent years has contributed to this same process.

Jola Skulj writes in her above cited paper that the "problematic of cultural identity undoubtedly refers us to a question of cross-cultural interactions. Considered this way, it is pre-eminently a concept belonging to the field of comparative literature"

(<http://docs.lib.purdue.edu/clcweb/vol2/iss4/5/>). For Skulj, literary works, genres, trends, and periods of artistic orientation in a given nation, as manifested through history, cannot exist as isolated events of the closed national existence of cultural history and cannot be understood without contacts with literary phenomena of other national cultures and it is precisely this problematic of identity which concerns Françoise Lionnet in her essay, "Logiques métisses": Cultural Appropriation and Postcolonial Representations" in Postcolonial Subjects. She describes the practice of métissage as "the global mongrelization [...] of cultural forms [which] creates hybrid identities, and interrelated, if not overlapping, spaces. In those spaces, struggles for the control of means of representation and self-identification are mediated by a single and immensely powerful symbolic system: the colonial language and the variations to which it is subjected under the pen of (Francophone) writers who enrich, transform and creolize it" (322). Lionnet concerns herself with Francophone women writers not only within France but, significantly, in Africa, the Caribbean, and the Indian Ocean, describing their "incessant and playful heteroglossia" as "a site of creative resistance to the dominant conceptual paradigms" (321). The dynamism of these border zones constantly challenges our academic preconceptions and the desire to categorise. In fact, Lionnet argues that such literature actually predates the issues which concern cultural anthropologists. The examples of her chosen novels promote a better understanding of the cultural configurations studied by social scientists as they present us with the transformative processes of writers and their characters as subjects ra- 
ther than the objects of scientific study (323). Her quarrel, she says, is with history and the negative connotations accorded to such terms as "assimilation" and "acculturation" in the postcolonial context. Thus, herself exemplifying the very process she describes, Lionnet states that a new vocabulary is needed to describe "patterns of influence that are never unidirectional" and suggests the term "transculturation" as a means of rejecting the binarism of Self and Other, nationalism and internationalism, for example, and acknowledging reciprocal influence (325). Such is the contemporary dialectic, according to which the local and global are increasingly interrelated and must be understood in relation to each other, although simultaneously "universality would be an empty proposition without the gendered specificities offered by particular writers representing different cultural configurations" (339). And this is the foundational premise upon which the writers in this collection operate.

In their efforts to highlight the contemporary dialectic, the editors of Postcolonial Subjects have chosen a diverse range of essays. In "Writing (Jumping) Off the Edge of the World," for example, Lori Saint-Martin discusses the problematic relationship to feminism in the work of some new women writers from Quebec whose narrative strategies nevertheless focus on the feminine, resulting in what Saint-Martin terms "metafeminism." Nicole Houde, Louise Bouchard, and Francine Noël are given as examples of women who deal with such issues as women and language, women's place in culture and history, and relationships between women. However, they "contain few theoretical elements or political statements on women," preferring to approach the political through the personal (286). Approaching the contemporary dialectic from a different angle in "Rewriting 'America': Violence, Postmodernity and Parody in the Fiction of Madeleine Monette, Nicole Brossard, and Monique LaRue," Karen Gould examines the ways the writers she discusses refigure "America" from the point of view of gender, francophone minority culture, and transculturalism. In so doing, Gould like Lionnet signals "a break with the closed space of Quebec and a new form of 'continentalism' in Quebec letters" (189).

So far, we have seen the frequency with which issues of identity and ideological, metaphorical and/or physical "border crossings" recur. There is, however, another sort of border crossing, the impact of which must briefly be considered. In Postcolonial Identities David Williams opens it for inspection in his article "Cyberwriting and the Borders of Identity: 'What's in a Name' in Kroetsche's The Puppeteer and Mistry's Such a Long Journey?," when he questions "whether the nation state, or local culture, or even the concept of a substantial self can survive the communications revolution?" (55). Drawing on Derrida's gloomy observation that the "cybernetic program" has destroyed "all metaphysical concepts -- including the concepts of soul, of life, of value, of choice, of memory" (qtd. in Williams 56) and Roland Barthes's prediction that we are being "plunged into a false Nature" (qtd. in Williams 56), Williams states that contemporary readers and critics must question what really are "facts of nature." He gives the example of the exposure of transcultural systems of domination by raising questions about race and gender. Taking the issue one step further, he asks where we "re-draw the borders of an identity once based on the book?" (56) In order to deal with this difficult question, he chooses Robert Kroetsch's The Puppeteer and Rohinton Mistry's Such a Long Journey, considering them in the context of the movement from the spoken to the written to the computerised word. He considers the ability of alphabetic writing to interfere between the author and her/his idea. Indeed, the very act of naming "forcibly erect[s] boundaries which seem natural" (59). Yet, drawing on Kroetsch and Mistry, he attempts to show that "story does -- has always done -- what is not unique to the new technologies: it blurs the boundaries between subject-object division, does away with borders, displaces the binary of Self and Other" (71). In other words, there is no need to re-draw the borders of identity as they were never clearly defined in the first place. This is an interesting argument, particularly when considered in the light of Kitzie McKinney's essay "Memory, Voice, and Metaphor in the Works of Simone Schwarz-Bart" in Postcolonial Subjects: Schwarz-Bart, a Guadeloupean writer, privileges Caribbean, African, and European oral traditions in her work, as she "creates her own narrative métissage of Creole and French, oral and written sources, sound and image, history and myth" (22). In this way, she seeks to "recenter traditional oral genres" such that the speaking voice is no longer automatically Other. In this reading of Schwarz-Bart, McKinney is both agreeing and disagreeing with 
Williams: she is using the power of story to overcome the Self-Other opposition, but in doing so asserts that, in the previous instance, the opposition was clearly defined. According to McKinney, women's storytelling becomes a powerful site of "difference, resistance, endurance, and courage" (38). Rather than erecting barriers, it becomes a means of breaking them down, encouraging an acknowledgment of difference within a context of universality and what McKinney describes as "a difficult, delicate and endless process of initiation" (39).

Williams and McKinney are engaging with the same issue that fascinates most of the other scholars whose studies are reviewed here: that of the Self-Other paradigm, which introduces issues of race, ethnicity and nation, and the role of history, historiography and geography in their representation. As we have seen, Coundouriotis examines in her book the need to theorize a practice of history as well as the role of historical criticism within postcolonial studies. In discussing the relationship between history and fiction she discusses the development of a hybrid discourse wherein new authorial positions are established through narratives which challenge established perspectives. At this point the relationship between history, literature, and ethnography is foregrounded, as is the notion of authenticity. Vautier in her book approaches the question from a slightly different angle, by examining theories of postcolonialism and postmodernism and the reworkings of some historical, literary, and religious myths and political ideologies in recent historiographic novels from Quebec and English-speaking Canada. Vautier explains that the New World myth reclaims the past by working against traditional assumptions about the universality and transhistoricity of myth, which in turn leads to the creation of provisional and relative identities and reveals the existence of many postcolonialisms and challenges the assumption that all postcolonial texts are writing back to a single centre. We are, then, faced with a seemingly infinite number of border crossings -- whether physical or resulting from a diversity of languages, ethnicities and races co-existing in a single national territory. The editors of and the contributors to Postcolonial Subjects explore these possibilities in all their fullness, focusing in particular on the female body as a space of cultural exchange and a site of literal and/or metaphorical métissage. Regardless of the site, however, each of the texts discussed here functions as a border zone, and, as Lionnet explains, "In border zones, all of our academic preconceptions about cultural, linguistic or stylistic norms are constantly being put to the test by creative practices that make visible and set off the processes of adaptation, appropriation and contestation that govern the construction of identity in colonial and postcolonial contexts" (321-22).

Reviewer's Profile: Angeline O'Neill teaches comparative Indigenous and world literatures at The University of Notre Dame, Australia. She has published in the areas of Australian literature and comparative Indigenous literatures and co-edited, with Anne Brewster and Rosemary van den Berg, Those Who Remain Will Always Remember: An Anthology of Aboriginal Writing (Fremantle Arts Centre Press, 2000). E-mail:

<angeline@nd.edu.au>. 